\title{
Synthesis of cyclobutane fused $\gamma$-butyro lactones through intramolecular [2+2] photocycloaddition. Application in a formal synthesis of grandisol
}

\author{
Jagannath Panda, Sarita Ghosh and Subrata Ghosh* \\ Department of Organic Chemistry, Indian Association for the Cultivation of Science, Jadavpur, \\ Calcutta - 700 032, India \\ E-mail: ocsg@mahendra.iacs.res.in
}

\begin{abstract}
Dedicated to Professor T. R. Govindachari on the occasion of his $85^{\text {th }}$ birthday
(received 02 May 01; accepted 15 Oct 01; published on the web 23 Oct 01)
\end{abstract}

\begin{abstract}
An approach to the synthesis of cyclobutane fused $\gamma$-butyrolactones is described. The key step involves a $\mathrm{Cu}(\mathrm{I})$ catalysed intramolecular [2+2] photocycloaddition of 1,6-dienes in which the two alkene units are tethered through acetal oxygen. The resulting bicyclic lactols were then oxidised to provide the title compounds. The synthetic potential of these lactones is illustrated by a formal synthesis of grandisol.
\end{abstract}

Keywords: Cyclobutane fused butyrolactones, intramolecular, [2+2]photocycloaddition, bicyclic lactols, grandisol

\section{Introduction}

The cyclobutane ring is present in many naturally occurring molecules. Grandisol $\mathbf{1},{ }^{1}$ the pheromone $2^{2}$ hebellophyllene $3^{3}$ and kelsoene $4^{4}$ are a few representative examples. Cyclobutane derivatives are also extensively used as synthetic intermediates ${ }^{5}$ taking advantage of their inherent ring strain that renders them to undergo facile ring enlargement and ring cleavage. Thus development of methodologies for the synthesis of highly functionalised four membered rings is of continued interest. ${ }^{6}$ We envisaged that cyclobutane fused $\gamma$-butyro lactones represented by the general structure 5 may lead to access to the natural products 1-4. We herein, report $^{7}$ a general protocol for the synthesis of the cyclobutane fused $\gamma$-butyro lactones and its application in a formal synthesis of grandisol 1. 


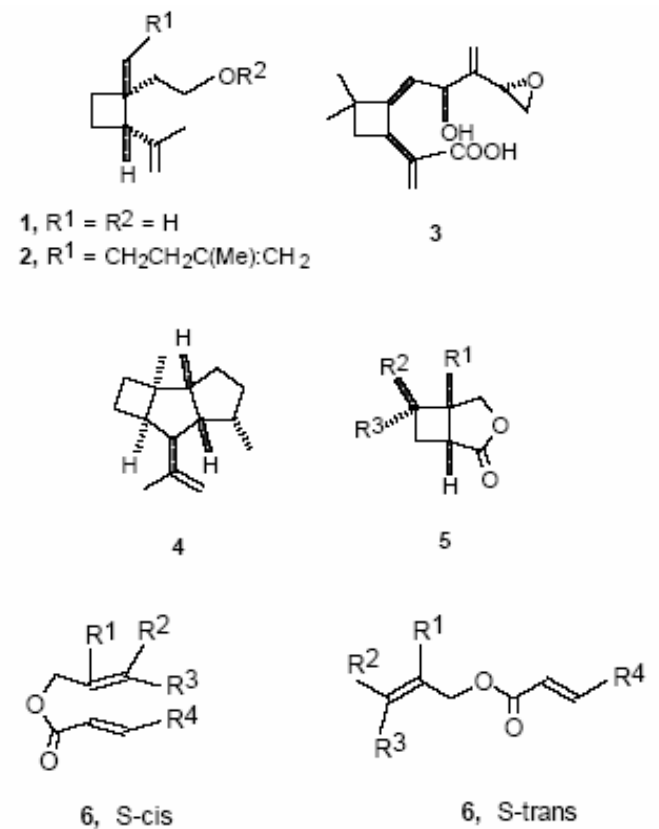

\section{Results and Discussion}

Retrosynthetically, the bicyclic lactone 5 should, in principle, be available through intramolecular [2+2] photocycloaddition of the dienes $\mathbf{6}$. However, UV irradiation of the diene 6

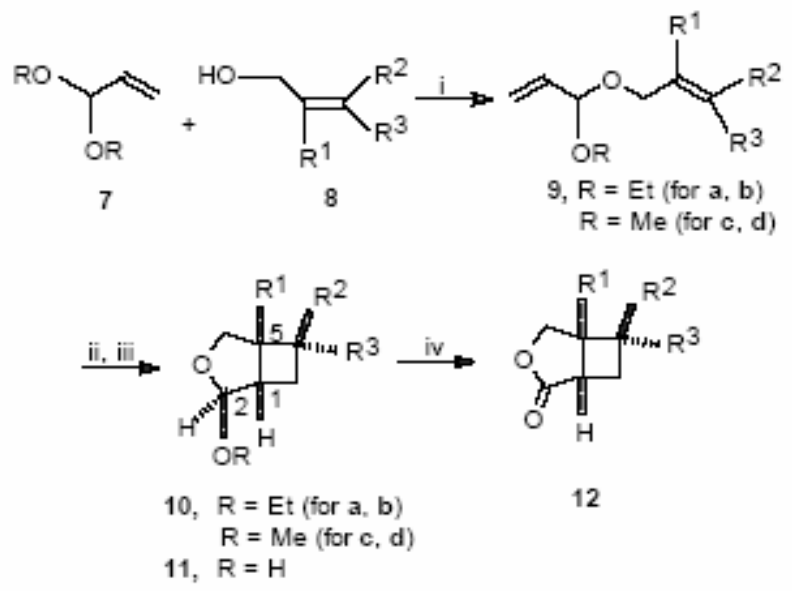

$$
\begin{aligned}
& \text { a, } R^{1}=H, R^{2}=R^{3}=M e \\
& b, R^{1}=H, R^{2}, R^{3}=H, M e \\
& \text { c, } R^{1}=R^{2}=R^{3}=H \\
& \text { d, } R^{1}=M e, R^{2}=R^{3}=H
\end{aligned}
$$

a, $\mathrm{R}^{1}=\mathrm{H}, \mathrm{R}^{2}=\mathrm{R}^{3}=\mathrm{Me} \mathbf{b}, \mathrm{R}_{1}=\mathrm{H}, \mathrm{R}_{2}, \mathrm{R}_{3}=\mathrm{H}, \mathrm{Me} \mathbf{c}, \mathrm{R}^{1}=\mathrm{R}^{2}=\mathrm{R}^{3}=\mathrm{H} \mathbf{d}, \mathrm{R}^{1}=\mathrm{Me}, \mathrm{R}^{2}=\mathrm{R}^{3}=\mathrm{H}$

Scheme -1 Reagents and Conditions : i, PPTS, $\mathrm{C}_{6} \mathrm{H}_{6}$, reflux, 1 h, (68-74\%); ii, hn, CuOTf, Et 2O, 5-6 h, (50-69\%); iii, 80\% AcOH, 80 o C, 3.5 h, (56-77\%); iv, Jones Reagent, $0{ }^{\circ} \mathrm{C}$-rt, 1 h, $(60-72 \%)\left(\mathrm{R}^{1}=\mathrm{R}^{2}=\mathrm{R}^{3}=\mathrm{H}, \mathrm{R}^{4}=\mathrm{CH}_{3}\right)$ 
failed to induce stylization even in the presence of sanitizers or metal catalysts, probably because the diene 6 exists in the most stable S-trans conformation ${ }^{8}$ rather than the less stable S-cis conformation required for cycloaddition. Salomon et. $a l^{9}$ has demonstrated that diallyl ether derivatives undergo smooth photobicyclisation to produce 3-oxabicyclo[3.2.0] heptanes in the presence of $\mathrm{Cu}(\mathrm{I})$ catalyst which brings the diene in the required S-cis conformation through formation of $\mathrm{Cu}(\mathrm{I})$ complex. Based on this observation we anticipated that photobicyclisation of the diene 9 (Scheme 1) in which the two $\pi$-units are tethered through an acetal oxygen, would produce the bicyclic lactol 10. Oxidation of the lactol 10 will then provide the desired lactone 11.

To begin, the diene 9a was prepared (Scheme 1) in 68\% yield through transacetalisation of acrolein diethyl acetal $7(\mathrm{R}=\mathrm{Et})$ with the allyl alcohol 8a in benzene under reflux with azeotropic removal of ethanol in the presence of PPTS as catalyst. Cycloaddition of the diene 9a was carried out in diethyl ether solution in the presence of cuprous trifluoromethane sulfonate (CuOTf) as catalyst by irradiating with quartz filtered light. The photoadduct 10a was isolated in $50 \%$ yield. The gross structure of the photoadduct 10a was established through its ${ }^{1} \mathrm{H}$ and ${ }^{13} \mathrm{C}$ NMR spectra.

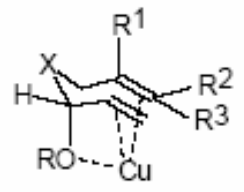

13a, $\mathrm{X}=\mathrm{CH}_{2}, \mathrm{R}=\mathrm{H}$ 13b, $X=O, R=E t$

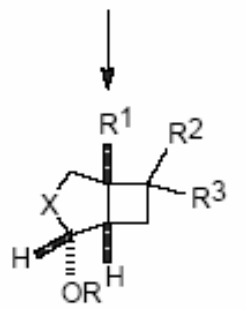

15a, $\mathrm{X}=\mathrm{CH}_{2}, \mathrm{R}=\mathrm{H}$ $15 b, X=O, R=E t$

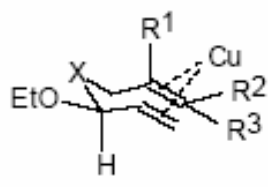

14
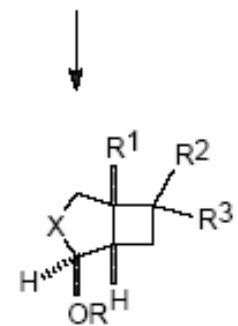

$10, X=O, R=$ Et or Me

The exo-stereochemical assignment to the photoadduct 10a was based on comparison of the coupling constant of the $\mathrm{C}_{2}-\mathrm{H}$ with those reported ${ }^{10}$ for analogous exo and endo-2-substituted-3oxabicyclo[3.2.0]heptanes. It has been reported that in exo-2-substituted-3oxabicyclo[3.2.0]heptanes, the $\mathrm{C}_{2}-\mathrm{H}$ which is trans to $\mathrm{C} 1-\mathrm{H}$ exhibits a coupling constant of 1.5 $\mathrm{Hz}$, while the $\mathrm{C}_{2}-\mathrm{H}$ which is cis to $\mathrm{C}_{1}-\mathrm{H}$ in the corresponding endo structure exhibits a higher coupling constant of $5.5 \mathrm{~Hz}$. The $\mathrm{C}_{2}-\mathrm{H}$ in the photoadduct 10a was found to appear at $\delta 4.82$ as a singlet i.e. with $J=0$. Thus $\mathrm{C}_{2}$ - and $\mathrm{C}_{1}$-hydrogens bear a trans relationship in the photo adduct 10a.

The formation of the adduct 10a with OEt group occupying an exo position is in contrast to the formation of the endo-adduct $\mathbf{1 5 a}$ from $\mathrm{Cu}(\mathrm{I})$ catalyzed photo cycloaddition of 3-hydroxy1,6-heptadiene. The latter reaction is believed ${ }^{11}$ to proceed through a tricordinated $\mathrm{Cu}(\mathrm{I})$ complex 13a. However, an analogous $\mathrm{Cu}(\mathrm{I})$ complex 13b with the bulkier OEt group occupying an endo 
position, necessary for formation of the endo-adduct $\mathbf{1 5 b}$, would be highly sterically crowded. Thus cycloaddition of the diene 3a takes place through the less crowded $\mathrm{Cu}(\mathrm{I})$ complex $\mathbf{1 4}$ resulting in exo adduct 10a.

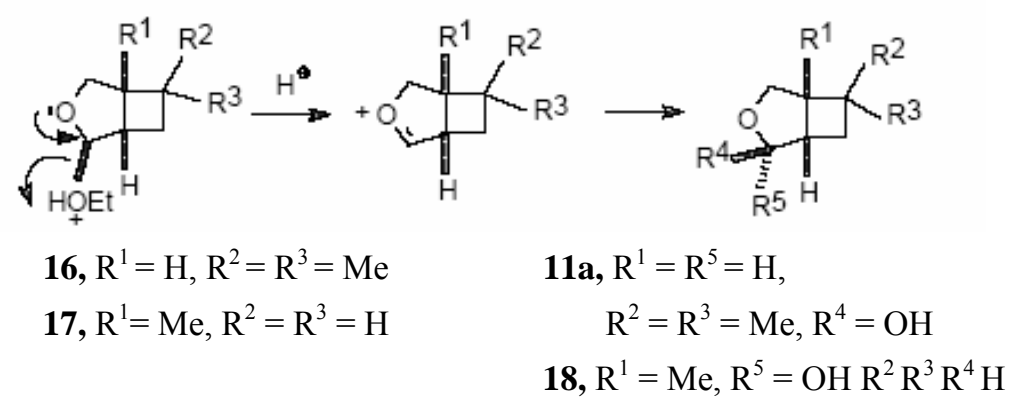

The photoadduct 10a was then treated with hot $80 \%$ aqueous acetic acid to afford the lactol 11a in $71 \%$ yield. Retention of configuration at $\mathrm{C} 2$-centre during deprotection was indicated by the appearance of the $\mathrm{C}_{2}-\mathrm{H}$ at $\delta 5.19$ as a singlet and is attributed to be the result of addition of $\mathrm{H} 2 \mathrm{O}$ to the intermediate oxonium ion $\mathbf{1 6}$ from the least hindered exo face. Oxidation of the lactol 11a finally afforded the lactone 12a in $68 \%$ yield. The generality of this four-step protocol was established by the synthesis of the lactones 10bd in very good yields. The diene $9 \mathbf{b}$, prepared from transacetalisation of acrolein diethyl acetal with crotyl alcohol, afforded the photoadduct 10b as a mixture of two diastereoisomers in 1:2.5 ratio as determined from the integration of the $\mathrm{C} 2-\mathrm{H}$ singlets at $\delta 4.79$ (minor isomer) and 4.90 (major isomer). The adduct 10b was converted to the lactone mixture 12b through oxidation of the corresponding lactols 11b.

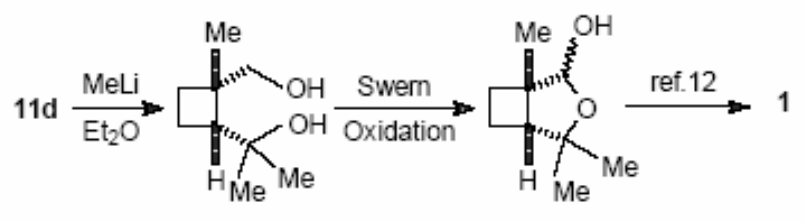

19

20

\section{Scheme -2}

The dienes 9c and 9d were prepared from transacetalisation of acrolein dimethyl acetal 7 ( R $=\mathrm{OMe}$ ) with allyl alcohol and methyallyl alcohol respectively. UV irradiation of these dienes in the presence of CuOTf afforded cycloadducts which underwent partial in situ demethylation, possibly through catalysis by $\mathrm{TfOH}$ generated from CuOTf during irradiation, to produce a mixture of the adducts 10c, 11c and 10d, 18 respectively. These lactols without characterisation, were directly treated with acid and the resulting products were oxidised with Jones reagent to provide the known lactones 12c and 12d. It is worth mentioning that in the lactol 18 the stereochemistry at $\mathrm{C}_{2}$ is opposite to those of the lactols 11a,b as indicated by the coupling constant of the $\mathrm{C}_{2}-\mathrm{H}$ which appeared as a doublet at $\delta 4.89(\mathrm{~J}=9.9 \mathrm{~Hz})$. The reversal of stereochemistry at $\mathrm{C}_{2}$ may be attributed to the addition of $\mathrm{H}_{2} \mathrm{O}$ to the oxonium ion $\mathbf{1 7}$ from the endo face as addition from the exo face is blocked by the $\mathrm{C}_{5}$-Me. 
The synthetic potential of the cyclobutane fused $\gamma$-butyro lactone is demonstrated by a formal synthesis of grandisol 1 (Scheme 2). The lactone 12d, on reaction with excess of MeLi, afforded the diol 19 in $71 \%$ yield. Swern oxidation of the diol 19 afforded the known diastereomeric mixture of the lactols 20. The mixture of lactols $\mathbf{2 0}$ has already been transformed ${ }^{12}$ to grandisol, thus accomplishing its formal synthesis. ${ }^{13}$

In conclusion transacetalisation of an acrolein acetal with allyl alcohol in conjunction with photocycloaddition and oxidation offers an excellent route to cyclobutane fused $\gamma$-butyro lactones. An application of this synthetic protocol has been demonstrated by a formal synthesis of grandisol.

\section{Experimental Section}

General Procedures. Compounds described here are all racemates. All reactions were carried out under an atmosphere of $\mathrm{N}_{2}$. Column chromatography was performed on silica gel (60-120 mesh). Petroleum refers to the fraction of petroleum ether bp $60-80{ }^{\circ} \mathrm{C}$. Ether refers to diethyl ether. Organic extracts were dried over anhydrous $\mathrm{Na}_{2} \mathrm{SO}_{4}$. IR spectra were recorded in thin film. Unless otherwise stated, ${ }^{1} \mathrm{H}$ and ${ }^{13} \mathrm{C}$ NMR spectra were recorded in $\mathrm{CDCl}_{3}$ solution at $300 \mathrm{MHz}$ and $75 \mathrm{MHz}$ respectively. Elemental analyses were carried out at the microanalytical laboratory of this laboratory.

3-Ethoxy-7-methyl-4-oxa-1,6-octadiene (9a). A mixture of 3-methyl-but-2-ene-1-ol (1g, $11.6 \mathrm{mmol})$, acrolein diethyl acetal $(3.7 \mathrm{~g}, 29 \mathrm{mmol})$, PPTS $(5 \mathrm{mg})$ and benzene $(12 \mathrm{~mL})$ was heated under reflux in an oil bath for $1 \mathrm{~h}$ with azeotropic removal of ethanol (Dean-Stark apparatus). On cooling, the reaction mixture was washed with aqueous $\mathrm{NaHCO}_{3}(2 \times 3 \mathrm{~mL}, 5 \%)$, dried and concentrated carefully in vacuum. The residual mass was chromatographed (etherpetroleum, 1:19) to afford the diene 9a in $68 \%$ yield; ${ }^{1} \mathrm{H}$ NMR $(60 \mathrm{MHz}) \delta\left(\mathrm{CCl}_{4}\right) 1.05(\mathrm{t}, J=7$ $\mathrm{Hz}, \mathrm{Me}), 1.66$ (s, Me), 1.73 (s, Me), 3.44 (q, $J=7 \mathrm{~Hz}, 1 \mathrm{H}), 3.49$ (q, $J=7 \mathrm{~Hz}, 1 \mathrm{H}), 3.89$ (d, $J=7$ $\mathrm{Hz}, 2 \mathrm{H}), 4.80(\mathrm{~m}, 1 \mathrm{H}), 5.06-6.10(\mathrm{~m}, 4 \mathrm{H})$.

3-Ethoxy-4-oxa-1,6-octadiene (9b). Following the above procedure, the diene 9b was prepared in 74\% yield; ${ }^{1} \mathrm{H}$ NMR $\delta 1.20(\mathrm{t}, J=6 \mathrm{~Hz}, 3 \mathrm{H}), 1.68(\mathrm{~d}, J=6 \mathrm{~Hz}, 3 \mathrm{H}), 3.4-3.6(\mathrm{~m}, 4 \mathrm{H}), 3.9-4.0$ $(\mathrm{m}, 2 \mathrm{H}), 4.9(\mathrm{~d}, J=3 \mathrm{~Hz}, 1 \mathrm{H}), 5.2-5.8(\mathrm{~m}, 5 \mathrm{H})$.

3-Methoxy-4-oxa-1,6-heptadiene (9c). The diene 9c was obtained in 72\% yield from the reaction of allyl alcohol and acrolein dimethyl acetal using the above procedure; ${ }^{1} \mathrm{H}$ NMR (60 $\mathrm{MHz})\left(\mathrm{CCl}_{4}\right) \delta 3.33(\mathrm{~s}, 3 \mathrm{H}), 4.08(\mathrm{~d}, \mathrm{~J}=6 \mathrm{~Hz}, 2 \mathrm{H}), 4.83-6.03(\mathrm{~m}, 7 \mathrm{H})$.

3-Methoxy-6-methyl-4-oxa-1,6-heptadiene (9d). The diene 9d was prepared in $68 \%$ yield from the reaction of methallyl alcohol and acrolein dimethyl acetal following the above procedure. ${ }^{1} \mathrm{H}$ NMR $(60 \mathrm{MHz})\left(\mathrm{CCl}_{4}\right) \delta 1.73(\mathrm{~s}, 3 \mathrm{H}), 3.23(\mathrm{~s}, 3 \mathrm{H}), 3.88(\mathrm{~s}, 2 \mathrm{H}), 4.80-6.23(\mathrm{~m}, 6 \mathrm{H})$. Purification of these volatile dienes for microanalysis led to rapid decomposition. 


\section{General procedure for [2+2] photocycloaddition}

exo-2-Ethoxy-6,6-dimethyl-3-oxa-bicyclo[3.2.0]heptane (10a). A solution of the diene 9a $(600 \mathrm{mg}, 3.5 \mathrm{mmol})$ in ether $(250 \mathrm{~mL})$ containing $\mathrm{CuOTf}(0.2 \mathrm{~g})$ was irradiated internally with a $450 \mathrm{~W}$ medium pressure mercury vapor lamp (Hanovia) through a double walled water cooled quartz immersion well for $5 \mathrm{~h}$. The reaction mixture was then washed with ice-cold aqueous $\mathrm{NH}_{4} \mathrm{OH}(2 \times 20 \mathrm{~mL}, 35 \%)$, dried and concentrated in vacuum. The residual oil was chromatographed (ether-petroleum, 1:19) to afford the cyclobutane derivative 10a (300 mg, $50 \%$ ) as a colorless liquid; ${ }^{1} \mathrm{H}$ NMR $\delta 0.93(\mathrm{~s}, 3 \mathrm{H}), 1.13(\mathrm{~s}, 3 \mathrm{H}), 1.16(\mathrm{t}, J=7.2 \mathrm{~Hz}, 3 \mathrm{H}), 1.73(\mathrm{~m}$, 2H), $2.45(\mathrm{~m}, 1 \mathrm{H}), 2.77(\mathrm{~m}, 1 \mathrm{H}), 3.41(\mathrm{q}, J=6.9 \mathrm{~Hz}, 2 \mathrm{H}), 3.74(\mathrm{dd}, J=6.3$ and $9.6 \mathrm{~Hz}, 1 \mathrm{H}), 3.96$ $(\mathrm{d}, J=9.6 \mathrm{~Hz}, 1 \mathrm{H}) ;{ }^{13} \mathrm{C} \mathrm{NMR} \delta 15.3\left(\mathrm{CH}_{3}\right), 23.9\left(\mathrm{CH}_{3}\right), 31.3\left(\mathrm{CH}_{3}\right), 32.6(\mathrm{C}), 35.5\left(\mathrm{CH}_{2}\right), 38.5$ $(\mathrm{CH}), 46.6(\mathrm{CH}), 62.1\left(\mathrm{CH}_{2}\right), 67.1\left(\mathrm{CH}_{2}\right), 107.4(\mathrm{CH})$. Anal. Calcd. for $\mathrm{C}_{10} \mathrm{H}_{18} \mathrm{O}_{2}: \mathrm{C}, 70.55 ; \mathrm{H}$, 10.66. Found, C, 70.87; H, 10.56.

exo-2-Ethoxy-6-methyl-3-oxabicyclo[3.2.0]heptane (10b). Obtained as a mixture of two diastereoisomers in 69\% yield as a colorless liquid; ${ }^{1} \mathrm{H}$ NMR $\delta 0.91\left(\mathrm{~d}, J=6.6 \mathrm{~Hz}, \mathrm{CH}_{3}\right.$ for minor diastereoisomer), 1.07 (d, $J=7.2 \mathrm{~Hz}, \mathrm{CH}_{3}$ for major diastereoisomer), 1.14 (t, $J=7.2 \mathrm{~Hz}$, $3 \mathrm{H}), 1.59(\mathrm{~m}, 1 \mathrm{H}), 1.83(\mathrm{~m}, 1 \mathrm{H}), 2.02(\mathrm{~m}, 1 \mathrm{H}), 2.45(\mathrm{~m}, 1 \mathrm{H}), 2.75(\mathrm{~m}, 1 \mathrm{H}), 3.37-4.00(\mathrm{~m}, 4 \mathrm{H})$, 4.79 ( $\mathrm{s}, \mathrm{C}_{2}-\mathrm{H}$ for minor diastereoisomer), $4.90\left(\mathrm{~s}, \mathrm{C}_{2}-\mathrm{H}\right.$ for major diastereoisomer); ${ }^{13} \mathrm{C} \mathrm{NMR} \delta$ $15.3\left(\mathrm{CH}_{3}\right), 16.1\left(\mathrm{CH}_{3}\right), 22.2\left(\mathrm{CH}_{3}\right), 27.0\left(\mathrm{CH}_{3}\right), 28.6\left(\mathrm{CH}_{2}\right), 29.5\left(\mathrm{CH}_{2}\right), 32.2(\mathrm{CH}), 39.5(\mathrm{CH})$, $40.8(\mathrm{CH}), 41.2(\mathrm{CH}), 44.8(\mathrm{CH}), 62.1(\mathrm{CH} 2), 66.1\left(\mathrm{CH}_{2}\right), 72.1\left(\mathrm{CH}_{2}\right), 107.5(\mathrm{CH}), 108.3(\mathrm{CH})$. Anal. Calcd. for $\mathrm{C}_{9} \mathrm{H}_{16} \mathrm{O}_{2}: \mathrm{C}, 69.19 ; \mathrm{H}, 10.32$. Found : C, 69.45; H, 10.02 .

6,6-Dimethyl-3-oxabicyclo[3.2.0]heptan-2-one (12a). A solution of the photo adduct 10a $(500 \mathrm{mg}, 2.9 \mathrm{mmol})$ in aqueous acetic acid $(10 \mathrm{~mL}, 80 \%)$ was heated in an oil bath at $80^{\circ} \mathrm{C}$ for $3.5 \mathrm{~h}$. Most of the acetic acid was removed from the reaction mixture in vacuum. The residual mass was dissolved in ether $(20 \mathrm{~mL})$. The ether layer was washed with saturated aqueous $\mathrm{NaHCO}_{3}(2 \times 5 \mathrm{~mL})$, dried and concentrated in vacuum. The residual mass was chromatographed (ether-petroleum, 1:3) to afford the lactol 11a (300 mg, 71\%); ${ }^{1} \mathrm{H}$ NMR $\delta 0.87(\mathrm{~s}, 3 \mathrm{H}), 1.09$ (s, $3 \mathrm{H}), 1.67-1.74(\mathrm{~m}, 2 \mathrm{H}), 2.45(\mathrm{t}, J=6.6 \mathrm{~Hz}, 1 \mathrm{H}), 2.71-2.79(\mathrm{~m}, 1 \mathrm{H}), 3.87(\mathrm{dd}, J=6.6,9.6 \mathrm{~Hz}$, $1 \mathrm{H}), 3.96(\mathrm{~d}, J=9.6 \mathrm{~Hz}, 1 \mathrm{H}), 5.19(\mathrm{~s}, 1 \mathrm{H})$. Without further characterization, it was oxidized according to the following procedure.

To a magnetically stirred solution of the lactol 11a $(250 \mathrm{mg}, 1.76 \mathrm{mmol})$ in acetone $(2 \mathrm{~mL})$ cooled to $0{ }^{\circ} \mathrm{C}$, was added drop wise Jones reagent $(0.5 \mathrm{~mL}, 0.7 \mathrm{M})$. The reaction mixture was stirred at $\mathrm{rt}$ for $1 \mathrm{~h}$, diluted with water $(5 \mathrm{~mL})$ and extracted with ether $(3 \times 5 \mathrm{~mL})$. The ether extract was washed with saturated aqueous $\mathrm{NaHCO}_{3}(4 \mathrm{~mL})$, dried and concentrated in vacuum. The residual mass was chromatographed (etherpetroleum, 1:5) to afford the lactone 12a (170 mg, 68\%); IR : $1772 \mathrm{~cm}^{-1} ;{ }^{1} \mathrm{H}$ NMR $\delta 1.14(\mathrm{~s}, 3 \mathrm{H}), 1.21(\mathrm{~s}, 3 \mathrm{H}), 1.95(\mathrm{dd}, J=3.9,12.3 \mathrm{~Hz}, 1 \mathrm{H}), 2.28$ $(\mathrm{dd}, J=10.2,12.3 \mathrm{~Hz}, 1 \mathrm{H}), 2.76$ (br t, $J=8.1 \mathrm{~Hz}, 1 \mathrm{H}), 3.04(\mathrm{~m}, 1 \mathrm{H}), 4.31$ (dd, $J=7.2,10.2 \mathrm{~Hz}$, $1 \mathrm{H}), 4.45(\mathrm{dd}, J=4.5,10.2 \mathrm{~Hz}, 1 \mathrm{H}) ;{ }^{13} \mathrm{C} \mathrm{NMR} \delta 15.3\left(\mathrm{CH}_{3}\right), 23.8\left(\mathrm{CH}_{3}\right), 31.1(\mathrm{CH}), 35.4(\mathrm{C})$, $37.8\left(\mathrm{CH}_{2}\right), 43.2(\mathrm{CH}), 69.1\left(\mathrm{CH}_{2}\right), 181.3(\mathrm{CO})$. Anal. Calcd for $\mathrm{C}_{8} \mathrm{H}_{12} \mathrm{O}_{2}: \mathrm{C}, 68.55 ; \mathrm{H}$, 8.63. Found : C, 68.32; H, 8.34.

6-Methyl-3-oxabicyclo[3.2.0]heptan-2-one (12b). Following the above procedure, the photo 
adduct 10b was transformed to the lactol 11b in $77 \%$ yield; ${ }^{1} \mathrm{H}$ NMR $(60 \mathrm{MHz}) \delta\left(\mathrm{CCl}_{4}\right) 0.85(\mathrm{~d}$, $J=7 \mathrm{~Hz}, \mathrm{CH}_{3}$ for minor diastereoisomer), $1.13\left(\mathrm{~d}, J=7 \mathrm{~Hz}, \mathrm{CH}_{3}\right.$ for major diastereoisomer), 1.68-2.90 (m, 5H), $3.85(\mathrm{~m}, 3 \mathrm{H}), 5.10(\mathrm{~s}, \mathrm{C} 2-\mathrm{H}$ for minor diastereoisomer), 5.20 (s, C2-H for major diastereoisomer). Anal. Calcd for $\mathrm{C}_{7} \mathrm{H}_{12} \mathrm{O}_{2}: \mathrm{C}, 65.60 ; \mathrm{H}, 9.44$. Found : $\mathrm{C}, 65.30 ; \mathrm{H}, 9.54$.

The lactol 11b was oxidized with Jones reagent to afford the lactone 12b in $72 \%$ yield; IR: $1770 \mathrm{~cm}^{-1} ;{ }^{1} \mathrm{H}$ NMR $\delta 1.14$ (d, $J=6.9 \mathrm{~Hz}, \mathrm{CH}_{3}$ for minor diastereoisomer), 1.16 (d, $J=6.9 \mathrm{~Hz}$, $\mathrm{CH}_{3}$ for major diastereoisomer), 1.76-1.83 (m, 0.5 H), 2.0-2.1 (m, 1H), 2.29-2.53 (m, 1.5 H), 2.67-2.80 (m, 1H), 2.99-3.20 (m, 1H), 4.21-4.50 (m, $2 \mathrm{H}) ;{ }^{13} \mathrm{C}$ NMR $\delta 16.3\left(\mathrm{CH}_{3}\right), 21.2\left(\mathrm{CH}_{3}\right)$, $28.8(\mathrm{CH}), 31.4\left(\mathrm{CH}_{2}\right), 31.5\left(\mathrm{CH}_{2}\right), 34.4(\mathrm{CH}), 34.7(\mathrm{CH}), 35.1(\mathrm{CH}), 36.1(\mathrm{CH}), 42.3(\mathrm{CH}), 68.6$ $\left(\mathrm{CH}_{2}\right), 73.3\left(\mathrm{CH}_{2}\right), 180.8(\mathrm{CO})$. Anal. Calcd for $\mathrm{C}_{7} \mathrm{H}_{10} \mathrm{O}_{2}: \mathrm{C}, 66.65 ; \mathrm{H}, 7.99$. Found: C, 66.49; H, 8.12 .

3-Oxabicyclo[3.2.0]heptan-2-one (12c). The crude product comprising of a mixture of the adducts 10c and 11c obtained after irradiation of the diene $9 \mathrm{c}$ on treatment with $\mathrm{HCl}(1 \mathrm{~N})$ for $1 \mathrm{~h}$ in dioxane afforded after chromatography the lactol 11c in 59\% yield; ${ }^{1} \mathrm{H}$ NMR $\delta 1.74(\mathrm{~m}, 2 \mathrm{H})$, $2.14(\mathrm{~m}, 3 \mathrm{H}), 2.90(\mathrm{~m}, 1 \mathrm{H}), 3.02(\mathrm{~m}, 1 \mathrm{H}), 3.87(\mathrm{~d}, J=9 \mathrm{~Hz}, 1 \mathrm{H}), 4.07$ (dd, $J=5.4,9 \mathrm{~Hz}), 5.38$ (s, $1 \mathrm{H}) ;{ }^{13} \mathrm{C}$ NMR $\delta 20.6\left(\mathrm{CH}_{2}\right), 23.7\left(\mathrm{CH}_{2}\right), 36.7(\mathrm{CH}), 44.0(\mathrm{CH}), 72.9\left(\mathrm{CH}_{2}\right), 103.9(\mathrm{CH})$. The lactol 11c was directly oxidised with Jones reagent as before to produce the known lactone 12c $\mathbf{c}^{8}$ in $60 \%$ yield; IR: $1763 \mathrm{~cm}^{-1} ;{ }^{1} \mathrm{H}$ NMR $\delta$ 2.09-2.23 (m, $\left.2 \mathrm{H}\right), 2.4-2.65(\mathrm{~m}, 3 \mathrm{H}), 3.13-3.24(\mathrm{~m}, 1 \mathrm{H})$, $4.26(\mathrm{~d}, J=9 \mathrm{~Hz}, 1 \mathrm{H}), 4.39$ (dd, $J=6.3$ and $9 \mathrm{~Hz}, 1 \mathrm{H})$.

5-Methyl-3-oxabicyclo[3.2.0]heptane-2-one (12d). The crude photoadducts 10d, 18 obtained after irradiation of the diene $9 \mathrm{~d}$ was converted to the lactol 18 in $56 \%$ according to the procedure for the synthesis of the lactone 12c; ${ }^{1} \mathrm{H}$ NMR $\delta 1.27(\mathrm{~s}, 3 \mathrm{H}), 1.65-2.12(\mathrm{~m}, 4 \mathrm{H}), 2.40(\mathrm{~m}, 1 \mathrm{H})$, 3.51-3.71 $(\mathrm{m}, 2 \mathrm{H}), 4.89(\mathrm{~d}, \mathrm{~J}=9.9 \mathrm{~Hz}, 1 \mathrm{H})$. Without further characterization, it was oxidized with Jones reagent as above to afford the lactone 12d in $68 \%$ yield; IR: $1774 \mathrm{~cm}^{-1} ;{ }^{1} \mathrm{H}$ NMR $\delta$ $1.35(\mathrm{~s}, 3 \mathrm{H}), 1.93-2.13(\mathrm{~m}, 2 \mathrm{H}), 2.22-2.28(\mathrm{~m}, 1 \mathrm{H}), 2.47-2.60(\mathrm{~m}, 1 \mathrm{H}), 2.69(\mathrm{dt}, J=2.6,9.8 \mathrm{~Hz}$, $1 \mathrm{H}), 3.96(\mathrm{~d}, J=9 \mathrm{~Hz}, 1 \mathrm{H}), 4.22(\mathrm{~d}, J=9 \mathrm{~Hz}, 1 \mathrm{H}) ;{ }^{13} \mathrm{C} \mathrm{NMR} \delta 20.5\left(\mathrm{CH}_{2}\right), 21.7\left(\mathrm{CH}_{3}\right), 31.09$ $\left(\mathrm{CH}_{2}\right), 43.08(\mathrm{CH}), 79.15\left(\mathrm{CH}_{2}\right), 41.6(\mathrm{C}), 180.7(\mathrm{CO})$. Anal. Calcd for $\mathrm{C}_{7} \mathrm{H}_{10} \mathrm{O}_{2}: \mathrm{C}, 66.65 ; \mathrm{H}$, 7.99. Found: C, 66.45; H, 7.75 .

1,4,4-Trimethyl-3-oxabicyclo[3.2.0]heptan-2-ol (19). To a magnetically stirred solution of the lactone $12 \mathrm{~d}(500 \mathrm{mg}, 3.96 \mathrm{mmol})$ in ether $(5 \mathrm{~mL})$ cooled to $-10^{\circ} \mathrm{C}$ was added $\mathrm{MeLi}(9.1 \mathrm{~mL}$, $11.83 \mathrm{mmol}, 1.3 \mathrm{M})$ in ether. The reaction mixture was slowly warmed to $\mathrm{rt}$ and stirring was continued for $12 \mathrm{~h}$. After quenching with saturated aqueous $\mathrm{NH}_{4} \mathrm{Cl}(1 \mathrm{~mL})$, the reaction mixture was extracted with ether $(3 \times 10 \mathrm{~mL})$. The organic extract was washed with brine $(2 \times 5 \mathrm{~mL})$, dried and concentrated in vacuum. The residual mass was chromatographed (ether-petroleum, 2:3) to afford the diol 19 (360 mg, 71\%) as a colorless liquid; ${ }^{1} \mathrm{H}$ NMR $\delta 1.08(\mathrm{~s}, 3 \mathrm{H}), 1.12(\mathrm{~s}, 3 \mathrm{H}), 1.25$ (s, 3H), 1.45-2.10 (m, 7H), $3.49(\mathrm{~d}, J=11.4 \mathrm{~Hz}, 1 \mathrm{H}), 3.72(\mathrm{~d}, J=11.4 \mathrm{~Hz}, 1 \mathrm{H}) ;{ }^{13} \mathrm{C}$ NMR $\delta 17.3$ $\left(\mathrm{CH}_{3}\right), 26.9\left(\mathrm{CH}_{2}\right), 28.5\left(\mathrm{CH}_{3}\right), 30.3\left(\mathrm{CH}_{2}\right), 45.0(\mathrm{C}), 54.7\left(\mathrm{CH}_{2}\right), 67.6(\mathrm{CH}), 72.8(\mathrm{C})$.

To a magnetically stirred solution of oxalyl chloride $(0.06 \mathrm{~mL}, 0.69 \mathrm{mmol})$ in dichloromethane $(2 \mathrm{~mL})$ at $-70{ }^{\circ} \mathrm{C}$, was added DMSO $(0.18 \mathrm{~mL}, 2.54 \mathrm{mmol})$. After stirring for $15 \mathrm{~min}$ a solution of the above diol $(40 \mathrm{mg}, 0.25 \mathrm{mmol})$ in dichloromethane $(2 \mathrm{~mL})$ was added to 
it. After stirring for $45 \mathrm{~min}$, triethylamine $(0.375 \mathrm{~mL}, 2.69 \mathrm{mmol})$ was added to it and the resulting reaction mixture was stirred at $\mathrm{rt}$ for $3 \mathrm{~h}$. It was poured into water $(2 \mathrm{~mL})$ and extracted with dichloromethane $(3 \times 5 \mathrm{~mL})$. The organic extract was dried and concentrated in vacuum. The residual mass was chromatographed to afford the lactol mixture $20(30 \mathrm{mg}, 63 \%)$; ${ }^{1} \mathrm{H}$ NMR $\delta$ $1.16\left(\mathrm{~s}, \mathrm{CH}_{3}\right), 1.23\left(\mathrm{~s}, \mathrm{CH}_{3}\right), 1.26\left(\mathrm{~s}, \mathrm{CH}_{3}\right), 1.27\left(\mathrm{~s}, \mathrm{CH}_{3}\right), 1.34\left(\mathrm{~s}, \mathrm{CH}_{3}\right), 1.6-2.1(\mathrm{~m}, 5 \mathrm{H}), 5.02(\mathrm{~d}$, $J=5.4 \mathrm{~Hz}, 1 \mathrm{H}), 5.12(\mathrm{~s}, 1 \mathrm{H}) ;{ }^{13} \mathrm{C} \delta 16.7,16.8,20.6,22.6,23.9,24.2,24.7,28.6,29.9,31.5,49.1$, 51.9, 52.9, 52.2, 52.9, 80.05, 84.05, 103.2, 104.9. ${ }^{1} \mathrm{H}$ and ${ }^{13} \mathrm{C}$ NMR data are comparable to the literature. $^{12}$

\section{Acknowledgements}

Financial support from CSIR, New Delhi through Grant No. 01(1625)/EMR is gratefully acknowledged. SG thanks CSIR for a Junior Research Fellowship.

\section{References}

1. Tumlinson, J. H.; Hardee, D. D.; Gueldner, R. C.; Thompson, A. C.; Hedin, P. A.; Miyard, J. P. Science, 1969, 166, 1010.

2. Fraga, M. B. Nat. Prod. Rep. 1999, 16, 711.

3. Wichlacz, M.; Ayer, W. A.; Trifonov, L. S. J. Nat. Prod. 1999, 62, 484.

4. Konig, G. M.; Koshino, H.; Funatsuki, K.; Kotoh, K. J. Chem. Soc., Chem. Commun. 1998, 1485.

5. (a) Samajdar, S.; Ghatak, A.; Ghosh, S. Tetrahedron Lett. 1999, 40, 4401. (b) Lange, L. G.; Gottarado, C.; Merica, A. J. Org. Chem. 1999, 64, 6738.

6. (a) For a review on [2+2] cycloaddition route to cyclobutanes see : Baldwin, J. E. In Comprehensive Organic Synthesis, Trost, B. M.; Ed., Pergamon Press: Oxford, 1991; Vol 5, p. 63 and Crimmins, M. T. In Comprehensive Organic Synthesis, Trost, B.M.; Ed., Pergamon Press: Oxford, 1991; Vol 5, p. 123. (b) For a recent approach see : Piers, E.; Boehringer, E. M.; Yee, J. G. K. J. Org. Chem. 1998, 63, 8642.

7. Preliminary communication: Panda, J.; Ghosh, S. Tetrahedron Lett. 1999, 40, 6693.

8. Deslongchamps, P. In Stereoelectronic Effects in Organic Chemistry, Pergamon Press: Oxford, 1983; Ch. 3, p. 54.

9. Ghosh, S.; Raychaudhuri, S. R.; Salomon, R. G. J. Org. Chem., 1987, 52, 83.

10. Gregori, A.; Alibes, R.; Bourdelande, J. L.; Font, J. Tetrahedron Lett. 1998, 39, 6961.

11. Salomon, R. G.; Coughlin, D. J.; Ghosh, S.; Zagorski, M. G. J. Am. Chem. Soc. 1982, 104, 998.

12. Hoffmann, N.; Scharf, H. D. Liebigs Ann. Chem. 1991, 1273.

13. For a recent synthesis of grandisol see: March, P. D.; Figueredo, M.; Font, J.; Raya, J. Organic Lett. 2000, 2, 163. 